Abstracta Iranica Abstracta Iranica

Revue bibliographique pour le domaine irano-aryen

Volume 30 | 2010

Comptes rendus des publications de 2007

\title{
Between Foreigners and Shi' is. Nineteenth Century Iran and its Jewish Minority. Stanford, Stanford University Press, 2007, 295 p., glossaire, bibliogr., index.
}

Jean Calmard

\section{(2) OpenEdition}

\section{Journals}

Édition électronique

URL : http://journals.openedition.org/abstractairanica/37801

DOI : 10.4000/abstractairanica.37801

ISSN : 1961-960X

Éditeur :

CNRS (UMR 7528 Mondes iraniens et indiens), Éditions de l'IFRI

Édition imprimée

Date de publication : 8 avril 2010

ISSN : 0240-8910

\section{Référence électronique}

Jean Calmard, «Between Foreigners and Shi'is. Nineteenth Century Iran and its Jewish Minority. Stanford, Stanford University Press, 2007, 295 p., glossaire, bibliogr., index. », Abstracta Iranica [En ligne], Volume 30 | 2010, document 152, mis en ligne le 08 avril 2010, consulté le 27 septembre 2020. URL : http:// journals.openedition.org/abstractairanica/37801 ; DOI : https://doi.org/10.4000/abstractairanica. 37801

Ce document a été généré automatiquement le 27 septembre 2020.

Tous droits réservés 


\title{
Between Foreigners and Shi'is.
} Nineteenth Century Iran and its Jewish Minority. Stanford, Stanford University Press, 2007, 295 p., glossaire, bibliogr., index.

\author{
Jean Calmard
}

Daniel Tsadik est l'auteur de nombreuses contributions sur les juifs d'Iran au XIX siècle. Certaines ont été recensées dans Abs. Ir. 28, 2005, c.r. $n^{\circ}$ 219, 271, 272. Il est aussi l'auteur d'une thèse intitulée : Foreign Intervention, Majority, and Minority: The Status of the Jews during the Latter Part of Nineteenth Century Iran (1848-1896), Phd, Yale University, 2002. Cet ouvrage est probablement une version élargie de cette thèse (dont il n'est fait mention qu'en bibliographie).

2 À travers les vicissitudes historiques, l'A. retrace les efforts du pouvoir qâjâr, souvent contrés par des religieux shiites et des éléments conservateurs de la société iranienne, pour améliorer le sort des juifs (et d'autres minorités religieuses). Soumis à diverses persécutions, ils en appellent aux organisations juives étrangères et aux diplomates en poste en Iran pour faire pression sur le gouvernement qâjâr. Basée sur un très grand nombre de sources, dont des archives conservées à Paris, Londres, Oxford, Jérusalem et diverses sources primaires et secondaires en arabe, persan, hébreu, et en langues occidentales, cette étude constitue la recherche la plus élaborée concernant le sort de la communauté juive d'Iran au XIX ${ }^{\mathrm{e}}$ siècle.

C.r. à paraître dans Studia Iranica. 
INDEX

Thèmes : 4.2.1. Safavides et Qâjârs

\section{AUTEURS}

JEAN CALMARD

CNRS - Paris 